\title{
A Behavioral Analysis of the Spatial Learning Deficit Induced by the NMDA Receptor Antagonist MK-801 (Dizocilpine) in the Rat
} Maria Åhlander, M.D., Ilga Misane, Ph.D., Pär A. Schött, M.S., and Sven Ove Ögren, Med.Dr.Sc.

This study analyzes whether the disruptive effects of the noncompetitive NMDA receptor antagonist MK-801 (0.01-0.1 mg/kg SC) on spatial learning can be dissociated from sensorimotor disturbances in the rat. Two different modifications of the Morris swim maze task with a hidden underwater platform were used: with or without local cue. Retention was tested either 24 h or 7 days after training as a probe trial (without platform). The present data indicate that MK-801 produces an impairment of spatial learning that cannot be dissociated from motor or sensory mechanisms. These findings support the view that NMDA receptors probably contribute to, but are not essential for, spatial learning in the water maze.

[Neuropsychopharmacology 21:414-426, 1999] (C) 1999 American College of Neuropsychopharmacology. Published by Elsevier Science Inc.
KEY WORDS: MK-801; NMDA receptors; Hippocampus; Spatial learning; Hidden platform; Cued platform; Motor performance; Sensory processing

A number of studies during the past decade have suggested a critical role of glutamatergic N-methyl-D-aspartate (NMDA) receptors in learning and memory processes (McEntee and Crook 1993; Rison and Stanton 1995). Induction of hippocampal long-term potentiation (LTP), a cellular model of neural plasticity (Bliss and Lomo 1973), has been shown to require the activation of NMDA receptors. On the other hand, antagonists of the NMDA receptors; for example, AP5, MK-801 (dizocilpine), and phencyclidine (PCP) have been shown to block hippocampal LTP in vitro and to impair hippo-

From the Department of Neuroscience (MA, PAS, SOO) Karolinska Institute, Stockholm, Sweden; and Laboratory of Pharmacology (IM), Latvian Institute of Organic Synthesis, Riga, Latvia. I. Misane is a postdoctoral fellow at the Department of Neuroscience, Karolinska Institute, Stockholm, Sweden.

Address correspondence to: S. O. Ögren, Division of Cellular and Molecular Neurochemistry, Department of Neuroscience, Karolinska Institute, S-171 77 Stockholm, Sweden.

Received June 12, 1998; revised September 23, 1998; accepted October 16, 1998. campal-dependent behavior; for example, place and spatial learning (Bischoff and Tiedtke 1992; Coan et al. 1987; Eichenbaum et al. 1990; Morris et al. 1986). These findings have led to the suggestions that NMDA receptors play a critical role in cognitive functions involving corticohippocampal circuits and that mechanisms underlying LTP and the behavioral manifestations of spatial learning are related (Collingridge et al. 1988; Harris et al. 1984; Morris et al. 1986).

MK-801 is a noncompetitive NMDA antagonist binding to the PCP binding site within the NMDA receptor ion channel, and it has negligible affinities for the sigma binding site and the dopamine uptake site (Snell et al. 1988; Wong and Nielsen 1989). Systemic administration of MK-801 produces an impairment in a variety of learning and memory paradigms; for example, passive avoidance (Ohno and Watanabe 1996) and such spatial tasks as the radial maze task (Pitkanen et al. 1995; Wozniak et al. 1990) and water maze tasks (Filliat and Blanchet 1995; Heale and Harley 1990; Kant et al. 1991; McLamb et al. 1990; Robinson et al. 1989; Whishaw and Auer 1989; Ylinen et al. 1995). MK-801 produces a doserelated spectrum of such motor dysfunctions as hyperactivity, stereotypies, or ataxia (Koek et al. 1988; Murata 
and Kawasaki 1993). In addition, NMDA receptor antagonists including MK-801 also affect certain aspects of sensory processing (al-Amin and Schwarzkopf 1996; Cain et al. 1997; Sillito et al. 1990; Tang and Ho 1988). Therefore, it is essential to determine whether learning and memory deficits caused by MK- 801 can be dissociated from nonspecific behavioral effects.

Several approaches have been used to dissociate sensorimotor impairments by MK-801 from those believed to be related to cognitive functions in the water maze tasks (Table 1). However, it is notable that in most of these studies, the behavioral responses of MK-801 have not been monitored in the water maze apparatus, i.e. in the context of learning. It is possible that the stress of being in the water may cointerfere with the disruptive effects of MK-801 on behavioral performance that can differ from those described in studies using observation cages (Sandi et al. 1997; Wedzony et al. 1994). The importance of performing a behavioral analysis during acquisition of the water maze task is clearly illustrated by recent studies using competitive NMDA receptor antagonists; for example, D,L-2-amino-5-phosphonovalerate (APV), NPC17742 and CGS19755 (Cain et al. 1996; Cain et al. 1997; Saucier et al. 1996).

The present studies were designed to investigate whether the effects of MK-801 on spatial learning could be dissociated from the effects on motor performance and sensory processing. Two different modifications of a Morris swim maze task (Morris 1981) were used: a classical hidden platform version and a cued platform version. Importantly, both the hidden and the cued platform were submerged below the water surface, thus avoiding differences in sensory perception of the platform in the two versions of the task.

This approach differs from the frequently used visible platform version in which the animal has to climb onto the platform protruding from the water (Cain et al. 1996; Cain et al. 1997; Saucier et al. 1996; Whishaw et al. 1995; Whishaw and Jarrad 1996; Whishaw and Tomie 1997). In the present study, retention was always tested

Table 1. Selected Studies on the Effects of MK-801 on Spatial Learning in the Water Maze Task.

\begin{tabular}{|c|c|c|c|}
\hline Reference & $\begin{array}{l}\text { Doses and Route of } \\
\text { Administration }\end{array}$ & $\begin{array}{c}\text { Effects in } \\
\text { Water Maze } \\
\text { Task }\end{array}$ & $\begin{array}{l}\text { Behavioral } \\
\text { Effects }\end{array}$ \\
\hline $\begin{array}{r}\text { Whishaw and } \\
\text { Auer (1989) }\end{array}$ & $\begin{array}{l}\text { Water maze: } \\
0.25,0.5,1,2,4 \\
\text { mg/kg IV } \\
\text { Locomotor cages: } \\
0.05,0.1 \mathrm{mg} / \mathrm{kg} \mathrm{IV}\end{array}$ & Escape latency $\uparrow$ & $\begin{array}{l}\text { Locomotor cages: } \\
\text { Motor activity } \uparrow \\
\quad(0.05 \text { and } 0.1 \mathrm{mg} / \mathrm{kg})\end{array}$ \\
\hline $\begin{array}{l}\text { Heale and } \\
\text { Harley (1990) }\end{array}$ & $\begin{array}{l}\text { Water maze and } \\
\text { open-field tests: } \\
0.07 \mathrm{mg} / \mathrm{kg} \mathrm{IP}\end{array}$ & Escape latency $\uparrow$ & $\begin{array}{l}\text { Open-field test: } \\
\text { Distance traveled } \uparrow\end{array}$ \\
\hline $\begin{array}{l}\text { Mc Lamb et al. } \\
\text { (1990) }\end{array}$ & $\begin{array}{l}\text { Water maze: } \\
0.05 \mathrm{mg} / \mathrm{kg} \mathrm{SC} \\
\text { Locomotor cages and } \\
\text { acoustic startle: } \\
0.0125,0.025,0.05 \\
\mathrm{mg} / \mathrm{kg} \mathrm{SC}\end{array}$ & Escape latency $\uparrow$ & $\begin{array}{l}\text { Locomotor cages: } \\
\text { Motor activity } \rightarrow \\
\text { Acoustic startle } \\
\quad \text { response } \rightarrow\end{array}$ \\
\hline $\begin{array}{l}\text { Filliat and } \\
\quad \text { Blanchet (1995) }\end{array}$ & $\begin{array}{l}\text { Water maze and } \\
\text { open-field tests: } \\
0.05,0.1 \\
0.2 \mathrm{mg} / \mathrm{kg} \mathrm{IP}\end{array}$ & $\begin{array}{l}\text { Escape latency } \uparrow \\
(0.2 \mathrm{mg} / \mathrm{kg})\end{array}$ & $\begin{array}{l}\text { Open-field test: } \\
\text { Ataxia scores } \uparrow \\
(0.1 \text { and } 0.2 \mathrm{mg} / \mathrm{kg}) \\
\text { Distance traveled } \uparrow \\
(0.05 \text { and } 0.1 \mathrm{mg} / \mathrm{kg}) \\
\text { Distance traveled } \rightarrow \\
(0.2 \mathrm{mg} / \mathrm{kg})\end{array}$ \\
\hline $\begin{array}{l}\text { Ylinen et al. } \\
\text { (1995) }\end{array}$ & $\begin{array}{l}\text { Water maze: } \\
\quad 0.075,0.15 \mathrm{mg} / \mathrm{kg} \text { IP }\end{array}$ & Escape distance $\uparrow$ & $\begin{array}{l}\text { Water maze: } \\
\text { Stay-on-platform time } \downarrow \\
\quad(0.075 \text { and } 0.15 \mathrm{mg} / \mathrm{kg}) \\
\text { Swim speed } \uparrow \\
\quad(0.075 \mathrm{mg} / \mathrm{kg}) \\
\text { Swim speed } \rightarrow \\
\quad(0.15 \mathrm{mg} / \mathrm{kg})\end{array}$ \\
\hline
\end{tabular}

The behavioral tests used in these studies discriminate unspecific drug effects from those on learning and memory.

$\uparrow=$ increase; $\downarrow=$ decrease; $\rightarrow=$ no effect. 
without platform (a probe trial). To investigate possible time-dependent effects of MK-801, retention was tested either $24 \mathrm{~h}$ or 7 days after training. In addition, after being tested for retention in the cued platform task, the animals were retrained in a reversal learning paradigm to examine their ability to use both spatial and nonspatial search strategies. The rats were video-recorded during the training sessions in the water tank to provide a detailed analysis of platform behaviors; for example, stay-on-platform time, grooming, wet-dog shakes, and rearing.

\section{MATERIALS AND METHODS}

\section{Subjects}

Male Sprague-Dawley rats weighing 300 to $350 \mathrm{~g}$ at the time of testing (corresponding to about 2 months of age) were obtained from B\&K Universal (Sollentuna, Sweden). The animals were housed in groups of four in standard plastic cages (Type IV Macrolon ${ }^{\circledR}$ ) in a temperature- and humidity-controlled room with a constant 12-h light/dark cycle (lights on at 6:00 am) and with free access to standard lab chow and tap water up to the time of the experiments. They were allowed to habituate to the animal maintenance facilities for a period of at least 5 days before initiation of the experiments. The experiments were conducted during the light period of the light/dark cycle, between 9:00 am and 3:00 pm. The animals were brought to the experimental room in plastic cages with specially designed tops (Micro-Isolator ${ }^{\circledR}$, ALAB-Stålstandard, Sweden), four animals per cage. A 60-min habituation period to the experimental room on the first day and 30-min on the following days preceded the learning experiments. Animal housing and all experimental procedures followed the provisions and general recommendations of the Swedish animal protection legislation. The experimental procedures were approved by the local Animal Ethics Committee (ethical number 79/96).

\section{Swim Maze Apparatus}

The water maze tests were performed in a circular water tank located in the center of an experimental room $(435 \times 295 \mathrm{~cm})$ surrounded by several extramaze cues, such as asymmetrically placed lamps, a black window, and a computer on a desk (Ögren et al. 1996). These extramaze cues were kept constant throughout the testing period. The circular tank was made from dark gray plastic, measuring $180 \mathrm{~cm}$ in diameter and $45 \mathrm{~cm}$ in height. The tank was filled with tap water (thermostatically controlled at $22 \pm 1^{\circ} \mathrm{C}$ ) up to a height of $28 \mathrm{~cm}$. The circular escape platform (15 $\mathrm{cm}$ in diameter) was made from dark gray plastic, exactly the same color as the water tank, and it was submerged $1 \mathrm{~cm}$ below the surface of the water. Pilot studies demonstrated that a platform submerged in clear water is invisible to the rats (black pool, clear water) (Ylinen et al. 1995). The present procedure differs from many studies in which milk powder or white polypropylene pellets are added to the water to create an opaque surface: (Morris 1981; Filliat and Blanchet 1995) (milk), (Heale and Harley 1990; McLamb et al. 1990) (milk powder), (Cain et al. 1993) (polypropylene pellets).

A digital system (Hitachi CCTV camera, model HV$720 \mathrm{~K}$ and an Ikegami 12-inch CCTV Picture monitor, PM-127) placed in the ceiling above the center of the water tank monitored several parameters of the swimming of the rats on line. The video camera was connected to a Victor VPCIIe computer and controlled by a computer program developed in cooperation between Epoc System and the Karolinska Institute (Ögren et al. 1996). The parameters monitored were latency to escape on the platform, swim distance, swim speed for each trial, and swim time and distance in each quadrant of the pool

\section{Experimental Procedure}

Once a day, different groups of rats received an injection of MK- 801 or saline 30 min before the first training trial. The animals were trained in the pool for 5 consecutive days, 4 trials/day. The pool was divided into four equally sized quadrants (north, east, south, and west). On day 1, the first trial was started from starting point "west." The starting points varied over the days of training, and they were rotated clockwise, one-quarter of a turn per trial (Schött et al. 1998). The platform remained in the center of the southeast quadrant throughout training. On each trial, the animals were lowered gently into the water, facing the wall of the pool and then released. At the same time, monitoring was started by means of a mouse connected to the computer. If the animals failed to find the platform within $60 \mathrm{~s}$, they were guided there by the experimenter's hand, and an extra $5 \mathrm{~s}$ were added to the escape latency time. Because many of the MK-801-treated rats did not follow experimenter's hand, they were moved and placed onto the platform. Animals were allowed to rest on the platform for $30 \mathrm{~s}$ after each trial (intertrial time). After the last trial, they were put in a drying cage and allowed to dry for at least $5 \mathrm{~min}$ before being returned to their experimental cages. Following training, the rats were brought back to the animal maintenance facilities and returned to their home cages. The retention test was conducted $24 \mathrm{~h}$ or 7 days after the last training session and always without platform (a probe trial), as described earlier (Ögren et al. 1996). 


\section{Experimental Design}

Three different experiments were performed to analyze the effects of MK-801. Rats were trained to find a hidden (submerged) or a cued (submerged with a visible cue) platform for a period of 5 consecutive days.

Experiments 1 and 2 (Exp. 1 and Exp. 2) were performed with a hidden platform. In Exp. 1, animals were divided into five groups with eight subjects in each receiving a different dose of MK-801 (0.01, 0.03, 0.05, and $0.1 \mathrm{mg} / \mathrm{kg}$, respectively). Retention was conducted 7 days after training. In Exp. 2, four groups of rats with 12 animals in each were used; groups 1 and 2 received 0.1 $\mathrm{mg} / \mathrm{kg}$ of MK-801, and groups 3 and 4 served as concurrent saline controls. Retention test in groups 2 and 3 took place $24 \mathrm{~h}$ after the last training session, and groups 2 and 4 were examined 7 days after the training. Because of an experimental error, four animals from group 1 were excluded from the experiment, leaving eight animals in this group.

In Exp. 3, the rats were divided into three groups with eight animals in each receiving either 0.05 and 0.1 $\mathrm{mg} / \mathrm{kg}$ of MK- 801 or saline, respectively. The stationary underwater platform was cued with a high contrast object, a yellow pen (12-18 cm height) attached to the center of the platform with a white plastic cup attached to the top of the pen and with a black-painted paper roof on the top of it all. By this design the cue (object) was not detectable to the video camera connected to the computer, but it provided a distinct visual discriminatory cue as to the position of the platform for the rats. Retention was tested $24 \mathrm{~h}$ after the last training session (day 6) without the platform, and thereupon the three groups of rats received the same drug treatment as during acquisition. The animals were retrained with the cued underwater platform in a new position; that is, in the middle of the quadrant opposite to the former position. This reversal training period lasted for a period of 2 consecutive days (days 6 and 7).

\section{Video Recording}

A JVC video camera placed on a video camera tripod located beside the water tank was used to record the behavior of the rats. In Exp. 2, five animals from each group of treatment (saline and the $0.1 \mathrm{mg} / \mathrm{kg}$ dose of MK-801), and in Exp. 3 five animals from the control group and eight animals from each treatment group were video recorded during the stay on the platform. In Exp. 2, the video recording took place on days 1, 3, and 5 of the training period; whereas, in Exp. 3, the animals were video recorded on each of the 5 days of training. From the video recordings, the following variables were analyzed: stay-on-platform time, number of fallings off the platform, wet-dog shakes (episodes of shaking the whole body), grooming (number of times wash- ing the face with the forepaws), and rearing (episodes of standing on the hind legs with the body in a vertical position). The average stay-on-platform time (four trials per animal and day) was calculated. For all other behavioral variables, only animals with a stay-on-platform time for the first $20 \mathrm{~s}$ and more of the total $30 \mathrm{~s}$ intertrial time were used in the statistical analysis, because the MK-801-treated animals displayed short stay-on-platform time (see below).

\section{Drugs}

MK-801 ((+)-10,11-dihydro-5-methyl-5H-dibenzo[a,d]cyclohepten-5,10-imine hydrogen maleate) was obtained from Sigma (St. Louis, MO, USA) and dissolved in saline $(0.9 \% \mathrm{NaCl})$. All injections were subcutaneous (SC) into the scruff of the neck at the volume of $2 \mathrm{ml} / \mathrm{kg}$.

\section{Statistics}

Over-all treatment effects in the swim maze studies were examined using a repeated measures two-way analysis of variance (ANOVA). Differences between treatment groups within days of treatment or between days within groups were analyzed using a factorial ANOVA. Comparisons between control groups and MK-801-treated groups were performed with the Fisher's PLSD-test. In addition, some behavioral variables were analyzed using ANOVA: stay-on-platform time, wet-dog shakes, and grooming. For analysis of the proportions of animals displaying rearing, the chisquare test and Fisher's exact probability test were used (Kirk 1968). A significance level of $p<.05$ was accepted as statistically significant.

\section{RESULTS}

\section{Effects of MK-801 on Acquisition and Retention in the Spatial Task}

Experiment 1: Dose-Related Effects of MK-801 in the Hidden Platform Task. Exp. 1 addressed the issue whether systemic (SC) administration of MK-801 would affect spatial learning in a dose-related manner. MK801 produced an over-all effect on escape latency $\left(\mathrm{F}_{4,35}=\right.$ $26.8, p<.001)$, swim distance $\left(\mathrm{F}_{4,35}=7.50, p<.001\right)$ and swim speed $\left(\mathrm{F}_{4,35}=25.28, p<.001\right)$ during acquisition (Figure 1). With regard to escape latencies, groups treated with 0.05 and $0.1 \mathrm{mg} / \mathrm{kg}$ of MK-801 differed significantly from the controls on all days of training; whereas, the $0.03 \mathrm{mg} / \mathrm{kg}$ group was significantly impaired only on the first day of training. The $0.1 \mathrm{mg} / \mathrm{kg}$ dose produced an impairment throughout the training period; whereas, the $0.05 \mathrm{mg} / \mathrm{kg}$ dose group, although clearly impaired, improved over days. The $0.03 \mathrm{mg} / \mathrm{kg}$ dose only tended to retard acquisition as compared to 


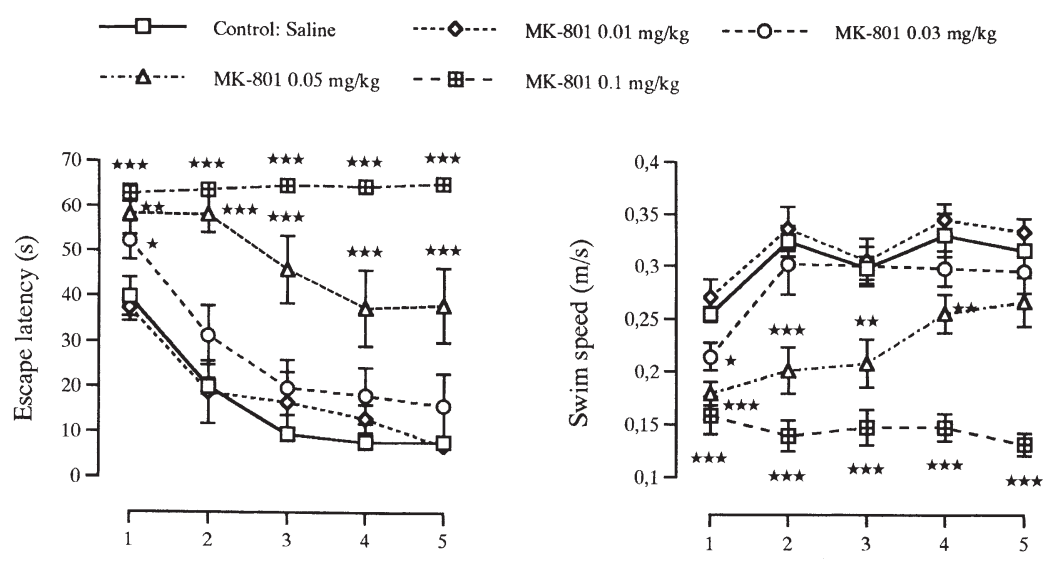

Training session (days)
Figure 1. Dose-dependent effects of MK801 on the acquisition in the hidden platform version of the spatial learning task. MK-801 $(0.01-0.1 \mathrm{mg} / \mathrm{kg}, \mathrm{SC})$ was injected $30 \mathrm{~min}$ before training (days 1-5). The saline (SC, 2 $\mathrm{ml} / \mathrm{kg}$ ) control group was run concurrently with MK-801-treated groups. The effects of MK-801 on swim speed and escape latency are shown. Each value represents the mean ( \pm SEM) in groups of eight animals. The statistical analysis was performed by a repeated measures of variance (ANOVA). Fisher's PLSD-test was used for pairwise group comparison: ${ }^{*} p<.05,{ }^{* *} p<.01$, and ${ }^{* * *} p<.001$ versus saline control group. For further details, see Materials and Methods. the controls over the days of training; whereas, the lowest $0.01 \mathrm{mg} / \mathrm{kg}$ dose did not affect acquisition at all. Treatment with the highest doses of MK-801 increased swim distance as compared to the control group on days 2 to 5 at the $0.1 \mathrm{mg} / \mathrm{kg}$ dose and on days 3 to 5 at the $0.05 \mathrm{mg} / \mathrm{kg}$ dose, respectively (data not shown). The swim speed was significantly decreased by the 0.05 $\mathrm{mg} / \mathrm{kg}$ and $0.1 \mathrm{mg} / \mathrm{kg}$ doses of MK-801. The decrease in swim speed at the $0.1 \mathrm{mg} / \mathrm{kg}$ dose of MK- 801 was seen throughout training; whereas, the decrease induced by the $0.05 \mathrm{mg} / \mathrm{kg}$ dose of MK- 801 was attenuated over the training days. The $0.03 \mathrm{mg} / \mathrm{kg}$ dose produced a decrease in swim speed only on day 1 .

Retention was measured in one single probe trial without the platform 7 days after the last training session (Table 2). Significant over-all differences were seen for escape latency $\left(\mathrm{F}_{4,35}=4.15, p<.01\right)$ and number of crossings $\left(\mathrm{F}_{4,35}=2.91, p<.05\right)$. The $0.05 \mathrm{mg} / \mathrm{kg}$ and 0.1 $\mathrm{mg} / \mathrm{kg}$ groups showed a significant impairment of retention $(p<.01$ for escape latency) (Table 2).
Experiment 2: Comparative Effects of the $0.1 \mathrm{mg} / \mathrm{kg}$ Dose of MK-801 on Retention Performed 24 h or 7 Days After the Last Training in the Hidden Platform Task. To investigate possible time-dependent effects of MK$801(0.1 \mathrm{mg} / \mathrm{kg})$, retention was tested $24 \mathrm{~h}$ and 7 days after training in Exp. 2. The results on acquisition were essentially in agreement with the results from Exp. 1. A significant over-all effect was noted for escape latency $\left(\mathrm{F}_{1,42}=344.7, p<.001\right)$ during the acquisition period. Similar results were obtained when swim distance $\left(\mathrm{F}_{1,42}=85.5, p<.001\right)$ and swim speed $\left(\mathrm{F}_{1,42}=64.4, p<\right.$ .001 ) were analyzed (data not shown).

Retention was tested $24 \mathrm{~h}$ after the last training session for groups 1 and 3 and 7 days after for groups 2 and 4 (Table 2). Escape latencies for the controls tested 7 days after the last training (group 4) were significantly longer compared to controls tested $24 \mathrm{~h}$ after the last training (group 2) $(p<.05)$. Thus, the time elapsed between training and retention test affected retention. For the groups 1 and 3, a significant effect was seen with re-

Table 2. Effects of MK-801 on Retention in the Hidden Platform Version of the Spatial Learning Task (Exps. 1 and 2)

\begin{tabular}{|c|c|c|c|c|c|c|c|c|}
\hline \multirow[b]{2}{*}{ Exp. 1} & \multicolumn{2}{|c|}{ Escape Latency (s) \pm SEM } & \multicolumn{2}{|c|}{ Number of Crossings \pm SEM } & \multicolumn{2}{|c|}{$\begin{array}{c}\text { Swim Distance in Target } \\
\text { Quadrant (\% Total Distance) }\end{array}$} & \multicolumn{2}{|c|}{$\begin{array}{c}\text { Number } \\
\text { Animals }(n)\end{array}$} \\
\hline & & & & & & & \multirow{2}{*}{\multicolumn{2}{|c|}{$n=8$}} \\
\hline Control: Saline & \multicolumn{2}{|c|}{$17.7 \pm 7.0$} & \multicolumn{2}{|c|}{$3.00 \pm 0.68$} & & & & \\
\hline MK-801 $0.01 \mathrm{mg} / \mathrm{kg}$ & \multicolumn{2}{|c|}{$26.8 \pm 8.3$} & \multicolumn{2}{|c|}{$2.50 \pm 1.24$} & & & \multicolumn{2}{|c|}{$n=8$} \\
\hline $\mathrm{MK}-8010.03 \mathrm{mg} / \mathrm{kg}$ & \multicolumn{2}{|c|}{$36.8 \pm 9.1$} & \multicolumn{2}{|c|}{$1.50 \pm 0.50$} & & & \multicolumn{2}{|c|}{$n=8$} \\
\hline MK-801 0.05 mg/kg & \multicolumn{2}{|c|}{$50.5 \pm 8.7^{* *}$} & \multicolumn{2}{|c|}{$0.75 \pm 0.41^{*}$} & & & \multicolumn{2}{|c|}{$n=8$} \\
\hline MK-801 $0.1 \mathrm{mg} / \mathrm{kg}$ & \multicolumn{2}{|c|}{$57.9 \pm 7.1^{* *}$} & \multicolumn{2}{|c|}{$0.13 \pm 0.13^{* *}$} & & & \multicolumn{2}{|c|}{$n=8$} \\
\hline Exp. 2 & $\begin{array}{l}\text { Retention } \\
(24 \mathrm{~h})\end{array}$ & $\begin{array}{l}\text { Retention } \\
\text { (7 days) }\end{array}$ & $\begin{array}{l}\text { Retention } \\
\quad(24 \mathrm{~h})\end{array}$ & $\begin{array}{l}\text { Retention } \\
\text { (7 days) }\end{array}$ & $\begin{array}{l}\text { Retention } \\
\quad(24 \mathrm{~h})\end{array}$ & $\begin{array}{l}\text { Retention } \\
\text { (7 days) }\end{array}$ & $24 \mathrm{~h}$ & 7 days \\
\hline Control: Saline & $11.2 \pm 2.8$ & $23.0 \pm 4.3$ & $3.58 \pm 0.45$ & $2.67 \pm 0.40$ & $35.7 \pm 2.4$ & $30.5 \pm 2.1$ & $n=12$ & $n=12$ \\
\hline MK-801 $0.1 \mathrm{mg} / \mathrm{kg}$ & $61.8 \pm 3.2^{* * *}$ & $50.7 \pm 6.7^{* *}$ & $0.13 \pm 0.13^{* * *}$ & $0.42 \pm 0.19^{* * *}$ & $23.0 \pm 2.9^{* *}$ & $19.5 \pm 1.7^{* * *}$ & $n=8$ & $n=12$ \\
\hline
\end{tabular}

MK-801 was administered subcutaneously (SC) 30 min before training (days 1-5). Retention was always examined without platform (a probe trial). In Exp. 1, retention was measured using the parameters escape latency and number of crossings. In Exp. 2, swim distance in the target quadrant was also included. In Exp. 1, rentention was assessed 7 days after the last day of training, in Exp. 2, it was assessed $24 \mathrm{~h}$ after the last day of training for half the groups and 7 days after for the other half. Over-all treatment effects were analyzed by repeated measures of variance (ANOVA). Fisher's PLSD-test was used to compare the different treatments versus corresponding saline controls ${ }^{*} p<.05,{ }^{* *} p<.01$, and $\left.{ }^{* * *} p<.001\right)$. For further details, see Materials and Methods. 
gard to escape latencies $\left(\mathrm{F}_{1,18}=139.6, p<.001\right)$ and number of crossings $\left(\mathrm{F}_{1,18}=37.2, p<.001\right)$. A marked difference between groups with regard to time spent and swim distance in target quadrant was also noted ( $p<.01$ for both). The saline group swam significantly longer distances and spent longer time in the target quadrant compared to all other quadrants.

When retention was examined 7 days after training (groups 2 and 4), a significant treatment effect on escape latency $\left(\mathrm{F}_{1,22}=12.1, p<.01\right)$ and number of crossings $\left(\mathrm{F}_{1,22}=26.1, p<.001\right)$ was noted (Table 2$)$. In addition, a profound $\left(\mathrm{F}_{1,22}=28.5, p<.001\right)$ difference in time spent in target quadrant was seen.

Experiment 3: Effects of MK-801 on Learning in the Cued Underwater Platform Task. Exp. 3 examined the effects of the $0.05 \mathrm{mg} / \mathrm{kg}$ and $0.1 \mathrm{mg} / \mathrm{kg}$ doses of MK-801 on acquisition of the water maze task using the cued platform version. MK-801 produced a marked impairment of acquisition at the $0.1 \mathrm{mg} / \mathrm{kg}$ dose (Figure 2). Significant over-all treatment effects were noted for escape latency $\left(\mathrm{F}_{2,21}=88.7, p<.001\right)$, swim distance $\left(\mathrm{F}_{2,21}=\right.$ 128.3, $p<.001)$, and swim speed $\left(\mathrm{F}_{2,21}=19.2, p<\right.$ .001). However, it is apparent that the $0.1 \mathrm{mg} / \mathrm{kg}$ group improved its performance over days of training. This improvement reached statistical significance on day 5 of training ( $\left.p_{\text {day } 5 \text { vs. day } 1}<.01\right)$. The $0.1 \mathrm{mg} / \mathrm{kg}$ dose of MK-801 also reduced swim speed during training, but this reduction was attenuated over days of training. In contrast, the $0.05 \mathrm{mg} / \mathrm{kg}$ dose did not impair acquisition, with the exception of day 1 ( $p<.01$ for escape latency). Furthermore, no effect on swim speed was seen at this dosage.

A retention test without the platform was performed $24 \mathrm{~h}$ after the last training session (day 6) (Table 3). This test was performed to examine whether the animals trained with a visually cued platform also had acquired spatial learning. The $0.05 \mathrm{mg} / \mathrm{kg}$ group did not differ significantly from the control group in escape latency to the former location of the platform, but showed a tendency for lower number of crossings $(p=.06)$. The 0.1 $\mathrm{mg} / \mathrm{kg}$ group was markedly impaired compared to the control group with regard to escape latency and number of crossings $(p<.001)$. Both the $0.05 \mathrm{mg} / \mathrm{kg}$ group $(p<.05)$ and the $0.1 \mathrm{mg} / \mathrm{kg}$ group differed $(p<.001)$ from the control in swim distance in target quadrant. For the control group, the swim distance in the target quadrant differed significantly from the other three quadrants, whereas this was not the case for the MK801-treated groups.

Reversal training was carried out directly after the retention test on day 6 (Figure 2). A change in the location of the cued platform to the opposite quadrant did not result into an impairment of acquisition in the control group (day 6 vs. day 5 of training). When comparing the escape latencies of the first trials of the days
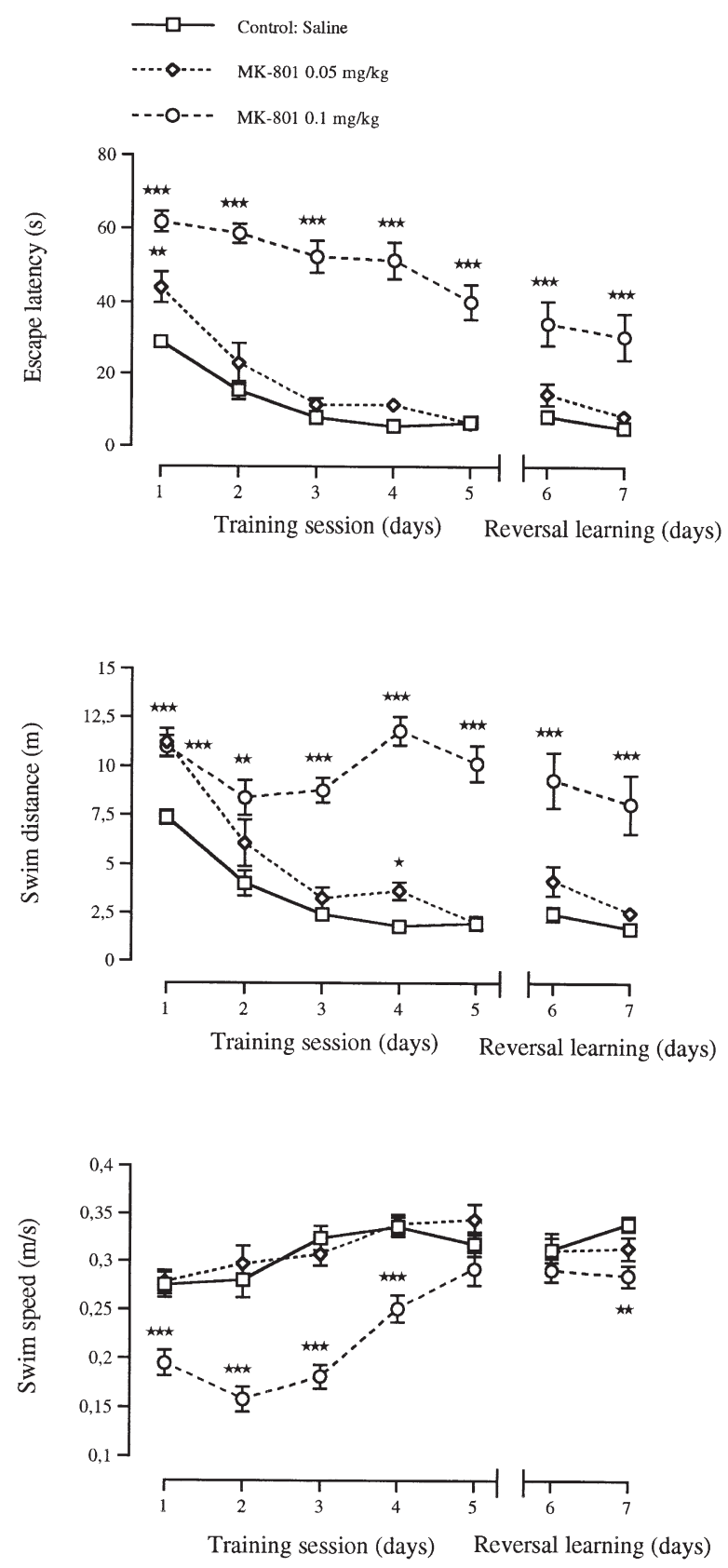

Figure 2. Effects of MK-801 on the acquisition in the cued platform version of the water maze task and the acquisition of a new position of the cued platform $24 \mathrm{~h}$ after the last day of training (reversal learning paradigm). MK-801 (0.05 and $0.1 \mathrm{mg} / \mathrm{kg}$, SC) was injected $30 \mathrm{~min}$ before training during the acquisition period (days 1-5) and the reversal learning period (days 6 and 7). The saline (SC, $2 \mathrm{ml} / \mathrm{kg}$ ) control group was run concurrently with $\mathrm{MK}-801-$ treated groups: Top panel: escape latency; middle panel: swim distance; bottom panel: swim speed. Each value represents the mean $( \pm$ SEM). ${ }^{*} p<.05,{ }^{* *} p<.01$, and ${ }^{* * *} p<.001$ versus saline control group. For further details see legend to Figure 1. 
Table 3. Effects of MK-801 on Retention in the Cued Platform Version of the Water Maze Task

\begin{tabular}{|c|c|c|c|c|c|c|c|}
\hline Treatment & $\begin{array}{c}\text { Escape } \\
\text { Latency } \\
\text { (s) } \pm \text { SEM }\end{array}$ & $\begin{array}{c}\text { Comparison } \\
\text { with Hidden } \\
\text { Platform }\end{array}$ & $\begin{array}{l}\text { Number of } \\
\text { Crossings } \pm \\
\text { SEM }\end{array}$ & $\begin{array}{c}\text { Comparison } \\
\text { with Hidden } \\
\text { Platform }\end{array}$ & $\begin{array}{c}\text { Swim Distance } \\
\text { in Target Quadrant } \\
\text { (\% Total Distance) }\end{array}$ & $\begin{array}{c}\text { Comparison } \\
\text { with Hidden } \\
\text { Platform }\end{array}$ & $\begin{array}{l}\text { Number } \\
\text { Animals }\end{array}$ \\
\hline Control: Saline & $17.5 \pm 7.9$ & $p=.39$ & $2.88 \pm 0.67$ & $p=.37$ & $36.3 \pm 2.9$ & $p=.67$ & $n=8$ \\
\hline MK-801 $0.05 \mathrm{mg} / \mathrm{kg}$ & $26.1 \pm 7.9$ & & $1.63 \pm 0.32$ & & $27.9 \pm 4.2^{*}$ & & $n=8$ \\
\hline MK-801 $0.1 \mathrm{mg} / \mathrm{kg}$ & $56.2 \pm 5.1^{* * *}$ & $p=.37$ & $0.38 \pm 0.18^{* * *}$ & $p=.28$ & $20.3 \pm 3.2^{* * *}$ & $p=.50$ & $n=8$ \\
\hline
\end{tabular}

MK-801 was administered (SC) 30 min before training (days 1-5). Retention was examined without platform (a probe trial) $24 \mathrm{~h}$ after the last training day (day 6). Escape latency, number of crossings, and percentage swim distance in the target quadrant were measured. The retention in the cued platform version and in the hidden platform version for the corresponding treatments were compared. ${ }^{*} p .05$ and ${ }^{* * *} p<.001$ versus saline control group. For further details, see Materials and Methods and Table 2.

(day 6 vs. day 5), no difference was found in the control group, and only a tendency for a longer latency was seen in the MK-801 $0.05 \mathrm{mg} / \mathrm{kg}$ group $(p=.06)$. Rats treated with $0.1 \mathrm{mg} / \mathrm{kg}$ of MK-801 were not further impaired when comparing the escape latencies on day 6 versus day 5 . However, the $0.1 \mathrm{mg} / \mathrm{kg}$ group was still markedly impaired throughout the period of reversal learning as compared to the control group.

A comparison between Exp. 2 (hidden platform) and Exp. 3 (cued platform) indicated that the control group was clearly faster in finding the cued platform as compared to the hidden platform $\left(\mathrm{F}_{1,30}=16.6, p<.001\right)$. However, no improvement was found in the MK-801 $0.1 \mathrm{mg} / \mathrm{kg}$ group in the presence of the cued platform $\left(\mathrm{F}_{1,26}=1.12, p=.30\right)$. The groups from Exp. 3 were also compared to their corresponding groups from Exp. 2 for retention. No significant differences were found either for escape latencies, number of crossings, or swim distance in target quadrant (Table 3).

\section{Analysis of Swimming and Platform Behavior}

During the first trials, the control animals swam along the wall of the pool, occasionally they tried to escape from the pool by rapid scratching on the wall. However, controls quickly developed an efficient search strategy as evidenced by their swim latencies to find the platform. On the platform, the control rats showed a characteristic pattern of behavior, consisting of explorative locomotor activity and rearing, which was gradually reduced over the days of training (Table 4 ). In contrast, the rats receiving the highest dose of MK-801 (0.1 $\mathrm{mg} / \mathrm{kg}$ ) during the first session displayed floating, diving, circling, and swimming along the edge of the swimming pool as well as scratching with their forepaws on the wall. However, this group of animals persisted to swim in the periphery (thigmotaxic swimming) throughout the entire training period; whereas, other aberrant behaviors were markedly reduced over the days of training. The MK-801-treated animals were also unable to follow the experimenter's hand when guided to the platform and when moved to be placed onto the platform, they displayed "fictive" locomotor hyperactivity. In addition, MK-801-treated animals remained hyperactive in the drying cage and demonstrated a profound cage-leaving response.

The MK-801 $0.1 \mathrm{mg} / \mathrm{kg}$ group also displayed an altered platform behavior, expressed as a reduction in stay-on-platform time, falling off the platform, and a complete abolishment of rearing. In contrast, such other motor responses as wet-dog shakes, forepaw tremor, and grooming were increased in the MK-801-treated rats. Importantly, the MK-801-treated groups did not show such fearlike behaviors as crouching and vocalization, and when handled they failed to show defensive/aggressive responses.

The animals were video recorded during their stay on the platform in Exps. 2 and 3. The results from Exp. 3 (cued platform) for three different variables (stay-onplatform time, wet-dog shakes, and grooming) are shown in Figure 3. There was an overall significant treatment effect of stay-on-platform time $\left(\mathrm{F}_{2,18}=8.83\right.$, $p<.01)$. The control animals and MK-801 $0.05 \mathrm{mg} / \mathrm{kg}$ group stayed on the platform throughout testing (Figure 3). In contrast, the $0.1 \mathrm{mg} / \mathrm{kg}$ MK- 801 group displayed a marked reduction in stay-on-platform time on the first 2 days of the acquisition period $\left(p_{\text {day } 1}<.001\right.$ and $p_{\text {day } 2}<.01$ ) mainly attributable to a small number

Table 4. Effects of MK-801 on Time Spent on Platform in the Cued Version of the Water Maze Task (Exp. 3)

\begin{tabular}{lccccc}
\hline & \multicolumn{5}{c}{ Days of Testing } \\
\cline { 2 - 6 } Treatment & $\mathbf{1}$ & $\mathbf{2}$ & $\mathbf{3}$ & $\mathbf{4}$ & $\mathbf{5}$ \\
\hline Saline & $0 / 5$ & $0 / 5$ & $0 / 5$ & $0 / 5$ & $0 / 5$ \\
& $(0 \%)$ & $(0 \%)$ & $(0 \%)$ & $(0 \%)$ & $(0 \%)$ \\
MK-801 & $4 / 8$ & $0 / 8$ & $0 / 8$ & $0 / 8$ & $0 / 8$ \\
$0.05 \mathrm{mg} / \mathrm{kg}$ & $(16 \%)$ & $(0 \%)$ & $(0 \%)$ & $(0 \%)$ & $(0 \%)$ \\
MK-801 & $8 / 8^{* * *}$ & $6 / 8^{*}$ & $3 / 8$ & $3 / 8$ & $0 / 8$ \\
$0.1 \mathrm{mg} / \mathrm{kg}$ & $(66 \%)$ & $(41 \%)$ & $(31 \%)$ & $(22 \%)$ & $(0 \%)$ \\
\hline
\end{tabular}

Rats were video recorded during their intertrial time. The results are expressed as the proportion of animals leaving the platform immediately $(0-1 \mathrm{~s})$ after being guided to, moved to the platform, or having encountered the platform themselves. The percentage of trials during which the rats left the platform is shown within brackets. The total number of animals were five animals in the saline group, and eight in each of the MK801-treated groups. Fisher's exact probability test was used for pairwise group comparisons: ${ }^{*} p<.05$ and ${ }^{* * *} p<.001$ versus saline control group. 

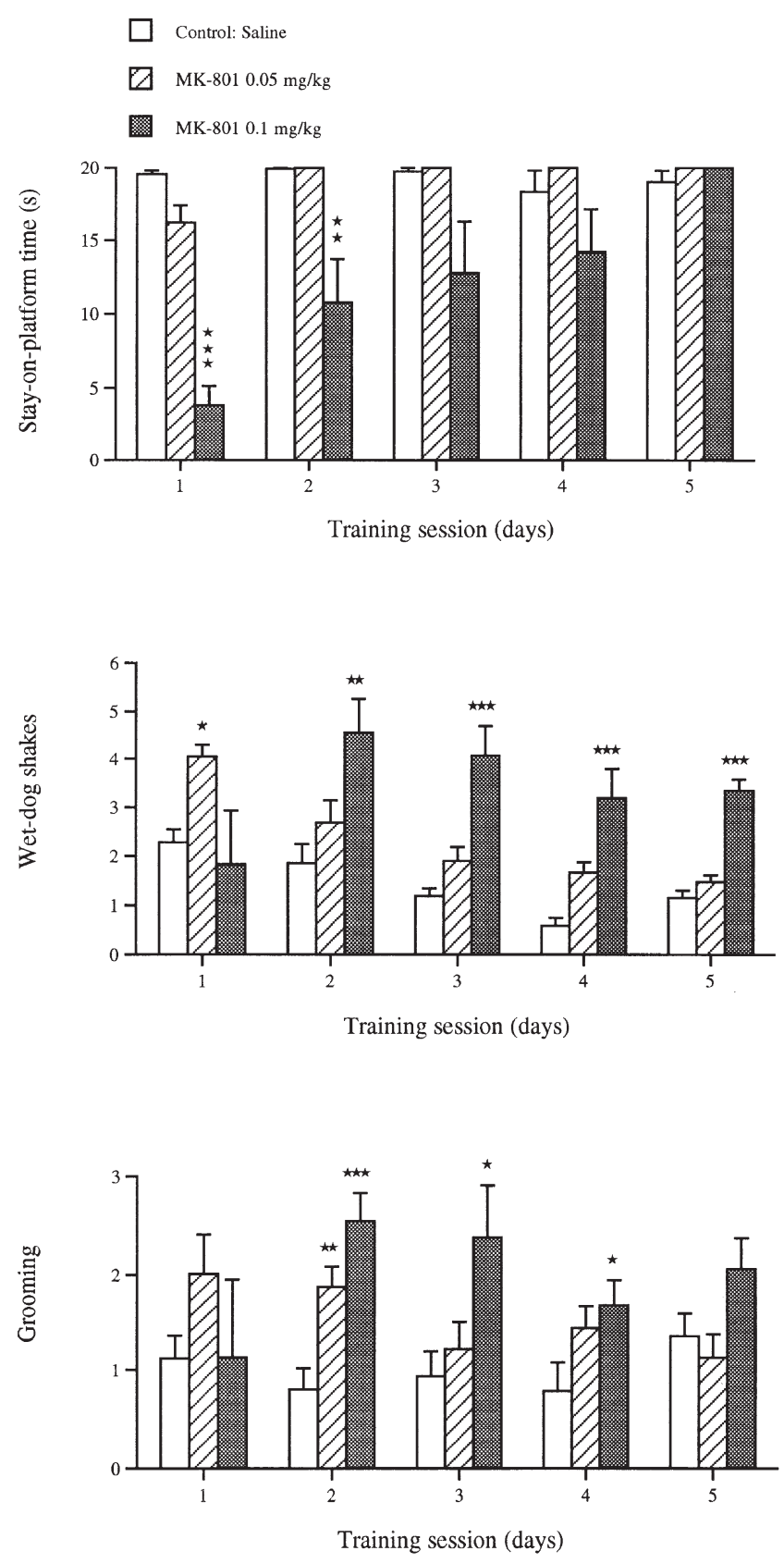

Figure 3. Effects of MK-801 on platform behavior during training (days 1-5) in the cued platform version of the water maze task (Exp. 3). MK-801 (0.05 and $0.1 \mathrm{mg} / \mathrm{kg}$, $\mathrm{SC}$ ) was injected $30 \mathrm{~min}$ before training. The saline (SC, 2 $\mathrm{ml} / \mathrm{kg}$ ) control group was run concurrently with MK-801treated groups. The behavior was video recorded and analyzed manually afterward. Only animals staying on the platform for the first $20 \mathrm{~s}$ and more during the $30 \mathrm{~s}$ intertrial interval were used in the calculations. Top panel: stay-on-platform time; middle panel: wet-dog shakes; bottom panel: grooming. The number of animals reaching the criterion of staying on the platform for the first $20 \mathrm{~s}$ and more at least one trial per day was $4 / 8,5 / 8,5 / 8,7 / 8$, and $8 / 8$ (training day 1-5) for the $0.1 \mathrm{mg} / \mathrm{kg}$ dose. For the 0.05 $\mathrm{mg} / \mathrm{kg}$ dose, the number was $8 / 8$ and for the control group $5 / 5$ throughout the entire training period (days 1-5). of swimovers and most commonly, immediate leaving of platform after being placed there. On day 1, the proportion of animals immediately (within $1 \mathrm{~s}$ ) leaving the platform was as follows (percentage of trials on which animals immediately left the platform are shown in the brackets): $0 / 5(0 \%)$ for saline controls; $4 / 8(16 \%)$ for MK-801 $0.05 \mathrm{mg} / \mathrm{kg}$ group; 8/8 (66\%) for MK-801 0.1 $\mathrm{mg} / \mathrm{kg}$ group. On days 2 to 5 , only animals treated with the $0.1 \mathrm{mg} / \mathrm{kg}$ dose were affected (Figure 3). Similar pattern of results was obtained in the hidden platform task (Fig. 4). A significant over-all treatment effect was also found for wet-dog shakes $\left(\mathrm{F}_{2,14}=19.1, p<.001\right)$ and grooming $\left(\mathrm{F}_{2,14}=8.93, p<.01\right)$. The MK-801 0.1 $\mathrm{mg} / \mathrm{kg}$ group displayed significant increase in wet-dog shakes on days 2 to 5 and the $0.05 \mathrm{mg} / \mathrm{kg}$ dose increased these responses on day 1 . Grooming was significantly increased in the $0.1 \mathrm{mg} / \mathrm{kg}$ group on days 2 to 4 , and it was significantly increased in the $0.05 \mathrm{mg} / \mathrm{kg}$ group only on day 2 . The analysis of platform behavior from Exp. 2 showed similar pattern (Figure 4).

Rearing was displayed by all animals in the control group at least on one trial during the entire training period; whereas, the MK-801-treated groups showed a dose-dependent reduction of rearing (MK-801 0.05 $\mathrm{mg} / \mathrm{kg}$ : 5 out of 8 ; MK-801 $0.1 \mathrm{mg} / \mathrm{kg}$ : 0 out of 8) (Table $4)$. The proportion of animals rearing in the control and the $0.05 \mathrm{mg} / \mathrm{kg}$ groups decreased over the days of training (Table 4).

\section{DISCUSSION}

\section{Hidden Platform Test: Spatial Learning and Sensorimotor Disturbances}

In the present study, the noncompetitive NMDA antagonist MK-801 (0.01-0.1 mg/kg SC) dose-dependently impaired acquisition and retention in the hidden platform test. A total blockade of acquisition was observed at the $0.1 \mathrm{mg} / \mathrm{kg}$ dose and a significant impairment at the $0.05 \mathrm{mg} / \mathrm{kg}$ dose (threshold dose). In previous studies, threshold doses of MK-801 shown to produce an impairment of acquisition ranged between 0.05 and 0.2 $\mathrm{mg} / \mathrm{kg}$ (Filliat and Blanchet 1995; Heale and Harley 1990; Kant et al. 1991; McLamb et al. 1990; Robinson et al. 1989; Whishaw and Auer 1989; Ylinen et al. 1995).

The main purpose of this study was to analyze whether the spatial learning impairment induced by MK-801 could be dissociated from its effects on sensorimotor processing. MK-801 given at the $0.1 \mathrm{mg} / \mathrm{kg}$ dose displayed a profound decrease in swim speed

Each value represents a mean \pm SEM. ${ }^{*} p<.05,{ }^{* *} p<.01$, and ${ }^{* * *} p<.001$ versus saline control group. For further details, see Materials and Methods and legend to Figure 2. 

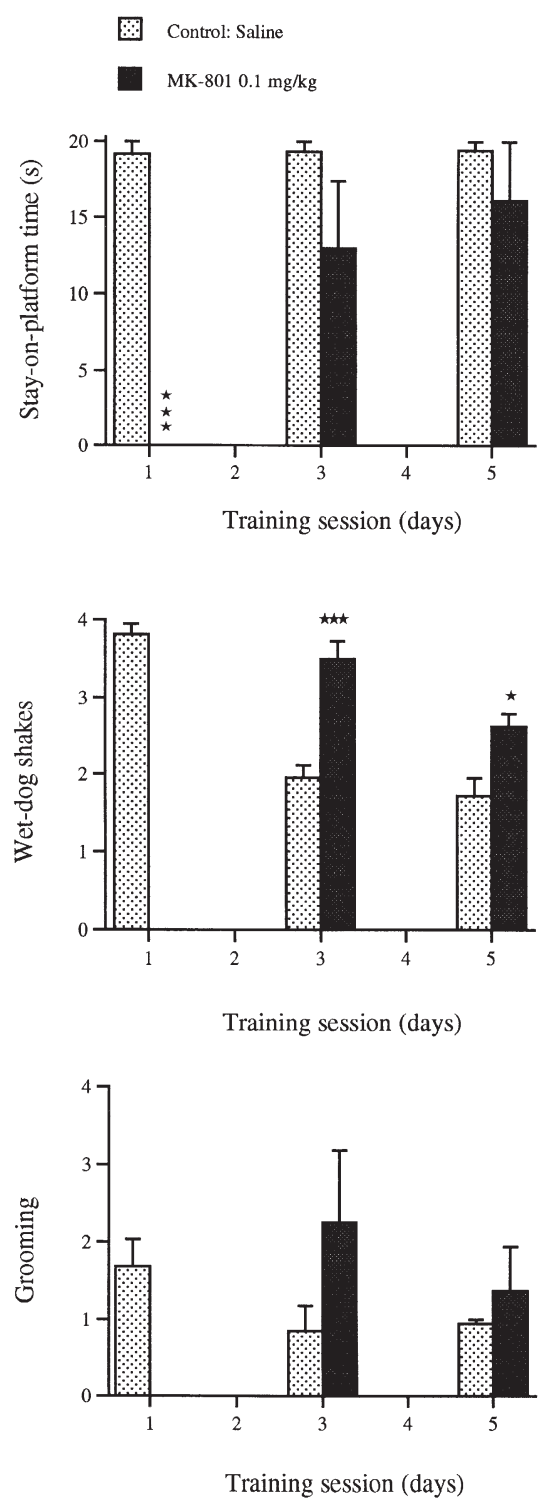

Figure 4. Effects of MK-801 on platform behavior in the hidden platform version of the water maze task (Exp. 2). MK801 (0.1 mg/kg, SC) was injected $30 \mathrm{~min}$ prior to training. The saline (SC, $2 \mathrm{ml} / \mathrm{kg}$ ) control group was run concurrently. Top panel: stay-on-platform time; middle panel: wetdog shakes; bottom panel: grooming. The number of animals in the $0.1 \mathrm{mg} / \mathrm{kg}$ group reaching the criterion of staying for the first $20 \mathrm{~s}$ at least one trial per day was $0 / 5$ (day 1 ), $4 / 5$ (day 3), and 4/5 (day 5). Each value represents a mean \pm SEM). ${ }^{*} p<.05$ and ${ }^{* * *} p<.001$ versus saline control group. For further details, see legend to Figure 3.

throughout the training period; whereas, this decrease was gradually attenuated over the days of experiment at the $0.05 \mathrm{mg} / \mathrm{kg}$ dose. When using the cued platform, the decrease in swim speed was only seen at the $0.1 \mathrm{mg} / \mathrm{kg}$ dose but not at the $0.05 \mathrm{mg} / \mathrm{kg}$ dose. This finding indicates that a salient cue can at least partly overcome the deficits in motor performance induced by MK-801.
Previous studies have reported both a decrease in swim speed (Robinson et al. 1989) and an increase in swim speed (Ylinen et al. 1995) at the same MK-801 dose $(0.08 \mathrm{mg} / \mathrm{kg})$; whereas, the $0.15 \mathrm{mg} / \mathrm{kg}$ dose failed to alter swim speed (Ylinen et al. 1995) (Table 1). The decrease in swim speed seems to contradict the behavioral hyperactivity observed in locomotor activity tests in the rat after treatment with MK-801 at the dose range of 0.05 to $0.1 \mathrm{mg} / \mathrm{kg}$ (Lehmann-Masten and Geyer 1991; Ögren and Goldstein 1994; Whishaw and Auer 1989). However, the altered swim performance in MK-801-treated rats in the hidden platform test was clearly not simply because of a disruption of coordinated leg movements. MK-801 causes also, loss of balance, ataxia at higher doses, and thigmotaxic swimming, which all contribute to the reduction in swim speed. Obviously, some aberrant behaviors in water, such as circling, diving, and floating noted after MK-801 treatment (Robinson et al. 1989; Whishaw and Auer 1989), particularly during the early training sessions, also contribute to the decrease in swim speed.

\section{Platform Behavior and Maze Acquisition}

The behavioral analysis showed that MK-801 reduced rearing on the platform at the 0.05 and $0.1 \mathrm{mg} / \mathrm{kg}$ doses. In locomotor studies, most investigators have found that MK-801 reduces rearing in the rat (Ford et al. 1989; Ögren and Goldstein 1994), although some studies showed no effect on rearing (Mathe et al. 1996). Rearing is often interpreted as an exploratory aspect of locomotor activity. It is apparent from the present data that the effects of MK-801 on exploratory behavior on the platform cannot be dissociated from other components of motor performance; for example, the ability to keep the balance as well as motivation (explorative drive).

Wet-dog shakes and grooming were included in the analysis, because they represent "natural" behavior of the rat and also are sensitive to changes in sensory input as well as drug treatment. The induction of wet-dog shakes in MK-801-treated rats could be related to an increase in 5-HT transmission, because this response is a component of the 5-HT syndrome (Bedard and Pycock 1977).

However, only high doses of MK-801 (>0.5 mg/kg) are reported to increase 5-HT neurotransmission in the rat brain (Hiramatsu et al. 1989; Loscher and Honack 1992). This finding suggests that the water exposureinduced stress in combination with a low dose of MK-801, might result in a further enhancement of serotonergic activity in the brain. There could also be a pharmacologic explanation for the increase in grooming by MK801, because this NMDA antagonist enhances dopamine (DA) transmission in vivo (Hiramatsu et al. 1989). Thus, grooming is elicited by stimulation of $\mathrm{DA} \mathrm{D}_{1}$ receptors (Molloy and Waddington 1984) and MK-801 is known to enhance $\mathrm{D}_{1}$ receptor-mediated motor responses (Goodwin et al. 1992; Morelli and DiChiara 1990). 
The animals in the control group displayed a reduction of grooming and wet-dog shakes over the days of the experiment, which was not the case for the MK-801treated groups. This observation might reflect a poorer ability of the MK- 801 treated animals to habituate to repeated sensory stimulation, as previously shown in the acoustic startle response test (al-Amin and Schwarzkopf 1996). Interestingly, there was no relationship between either grooming or wet-dog shakes and escape latency at the individual level (correlation coefficient $<0.40$ for all treatment days) indicating that these two platform behaviors are not directly related to task acquisition.

It is of particular interest that the $0.1 \mathrm{mg} / \mathrm{kg}$ dose of MK-801 significantly reduced stay-on-platform time in both the hidden and cued versions of the test. These results extend previous findings showing that acute administration of MK-801 can reduce the stay-on-platform time when examined in a nonlearning situation. This reduction has been interpreted as a result of motor hyperactivity (Ylinen et al. 1995). Moreover, in recent studies competitive NMDA antagonists clearly reduced time spent on a hidden platform (Cain et al. 1996; Cain et al. 1997). Our behavioral analysis suggests that the reduction of stay-on-platform time probably reflects a disturbance in sensorimotor processing; that is, the rats fail to associate the sensory input from their paws with the refuge from the water. This interpretation is supported by three observations. First, animals treated with the 0.1 $\mathrm{mg} / \mathrm{kg}$ dose, which during the first days of training hit the platform, swam over it. If the animals were placed onto the platform by the experimenter, they left it immediately. The "leaving" behavior was repeatedly seen during the first 2 days of training. This supports the view the stay-on-platform time is a prerequisite for the efficient acquisition of the spatial task. Second, the effect of MK-801 on platform performance was reduced over the training days; whereas the motor-stimulatory response to MK-801 was not reduced (compare Figures $1-4)$. Moreover, the proportion of animals staying on the platform correlated with acquisition performance, suggesting a relationship between mechanisms for learning and sensorimotor disturbances. Third, the effects of MK-801 on swim speed and escape latency were seen at both the 0.05 and $0.1 \mathrm{mg} / \mathrm{kg}$ doses; whereas, the effects on stayon-platform time were observed only at the $0.1 \mathrm{mg} / \mathrm{kg}$ dose. This is consistent with the observation that MK-801 affects brightness discrimination in the rat at the $0.3 \mathrm{mg}$ / $\mathrm{kg}$ dose; whereas, locomotor activity is changed already at the $0.1 \mathrm{mg} / \mathrm{kg}$ dose in a Y-maze task (Tang and Ho 1988).

\section{The Cued Platform task: Spatial and Nonspatial Factors}

The acquisition of the water maze task of the cued platform version was carried out to examine the potential role of disturbances in attention and sensory processing. In this task, the escape latencies in the control group were consistently lower as compared to those in the hidden platform task, indicating that these rats were able to make efficient use of a local cue. Unlike the hidden platform task (Exp. 1), rats treated with the 0.05 $\mathrm{mg} / \mathrm{kg}$ dose of MK-801 did not differ significantly (with the exception of day 1) from the controls in the cued platform test (compare Figures 1 and 2, respectively). In agreement with previous results (Robinson et al. 1989), rats treated with the $0.1 \mathrm{mg} / \mathrm{kg}$ dose of MK801 were severely impaired in both the cued as well as in the hidden platform test. This impairment seems not to be a result of visual disturbances, because acquisition performance after the change of platform location was somewhat better in the reversal learning paradigm than on the last day of training in the cued platform test (see Figure 2). Taken together, these findings give further support for the view that the $0.1 \mathrm{mg} / \mathrm{kg}$ dose of MK- 801 induces alterations in both sensory processing and motor performance that interfere with learning. The fact that rats treated with the $0.05 \mathrm{mg} / \mathrm{kg}$ dose of MK- 801 were unimpaired in the cued task suggests that the learning impairment seen in the hidden platform task was partly attributable to alterations in motor performance. Because performance in the cued platform task seems to be mediated by striatal mechanisms; whereas, the hidden platform task involves mainly hippocampal mechanisms (McDonald and White 1994), we could argue that differential effects on hippocampal function could explain the pattern of results observed. However, the present results indicate that MK-801 effects a large number of NMDA synapses in both sensory and motor systems consistent with the wide distribution of these receptors (Grillner et al. 1997). Therefore, there is no dose range of MK-801 that "selectively" affects learning and memory processes, contrary to what some investigators have concluded (Robinson et al. 1989; Wozniak et al. 1990).

The retention test without the platform (Exp. 3) was carried out to investigate whether the animals would acquire a spatial strategy when exposed to a visually cued platform. It could be hypothesized that under the conditions of the visually cued platform, the rats might not use extramaze cues when heading for the platform. In this version of the task, a memory of the spatial position of the platform seems not to be required for optimal performance. Therefore, we assumed that the controls trained in the cued platform task would display an impaired retention (memory) as compared to the controls trained with a hidden platform (Exps. 1 and 2). However, this hypothesis was not supported, because the control animals from the cued version remembered the spatial location of the platform in the probe trial as well as the controls from the hidden platform experiment. This finding indicates that control rats simultaneously 
acquired the knowledge on the spatial relations between the platform and the extramaze cues; that is, spatial learning when performing in the cued platform task.

Interestingly, the MK-801 $0.05 \mathrm{mg} / \mathrm{kg}$ group did not only learn the cued platform task nearly as well as the controls but remembered the spatial location of the platform almost as well as the controls, with regard to escape latencies in the retention test. This indicates that the cued platform that is required for task acquisition at the $0.05 \mathrm{mg} / \mathrm{kg}$ dose of MK-801 also contributes to certain aspects of the spatial memory of the task. This result is in partial disagreement with the study of Whishaw and Auer (1989), reporting that MK-801-treated animals (0.05 $\mathrm{mg} / \mathrm{kg}$ ) did not remember the location of a previously cued platform, although they had learned to escape to the platform during the acquisition period. However, the fact that the $0.1 \mathrm{mg} / \mathrm{kg}$ group did not display spatial memory of the location of the platform further emphasizes our view that memory performance after treatment with MK-801 depends upon the degree of acquisition.

\section{Effects of MK-801 on Reversal Learning}

NMDA receptor blockade is reported to affect the ability to use visually guided cues (Cain et al. 1997; Tang and Ho 1988). Therefore, the reversal learning paradigm using the cued platform was included to study the level of flexibility regarding search strategies and to examine any possible primary visual disturbances by MK-801. The MK-801-treated $(0.1 \mathrm{mg} / \mathrm{kg})$ rats gradually improved their performance in the reversal test (days 6 and 7) as compared to the last day of training (day 5) with the original platform position. This indicates that MK-801-treated rats can utilize visual cues, although their cue-mediated navigation abilities are impaired. Importantly, unlike rats with gross lesions of the hippocampus they did not return to the previous location of the platform after it had been moved to a new location (Morris et al. 1982; Whishaw et al. 1995; Whishaw and Jarrad 1996; Whishaw and Tomie 1997). In contrast, the $0.05 \mathrm{mg} / \mathrm{kg}$ group and the control group were slightly impaired in their acquisition performance on the first trials after the platform was moved to the new location indicating that these two groups used a spatial search strategy. However, the fact that their escape latencies were only slightly prolonged on the first retraining session, as compared to the last day of training, implies that they readily changed to use the local cue, which was the appropriate search strategy for the test situation.

\section{CONCLUSIONS}

The present findings show that MK-801 (0.01-0.1 mg/kg $\mathrm{SC}$ ) induces a dose-dependent impairment of acquisi- tion and retention in a spatial learning task with a threshold dose of $0.05 \mathrm{mg} / \mathrm{kg}$. This impairment can be partly overcome by a salient local cue on the platform.

MK-801 induced motor disturbances at the 0.05 and $0.1 \mathrm{mg} / \mathrm{kg}$ doses, and the $0.1 \mathrm{mg} / \mathrm{kg}$ dose also caused alterations in sensory processing. The results show that the effects of systemically administered MK-801 on spatial learning in the water maze task cannot be dissociated from motor and/or sensory disturbances. This supports the view that NMDA receptors probably contribute to, but seem not to be crucial for, spatial learning (Cain 1998; Cain et al. 1996; Saucier et al. 1996).

\section{ACKNOWLEDGMENTS}

This study was supported by grants from Stiftelsen Gamla Tjänarinnor, Loo och Hans Ostermans fond, Kapten Arthur Eriksson, and Karolinska Institutets forskningsfond.

\section{REFERENCES}

al-Amin HA, Schwarzkopf SB (1996): Effects of the PCP analog dizocilpine on sensory gating: Potential relevance to clinical subtypes of schizophrenia. Biol Psychiat 40:744754

Bedard P, Pycock CJ (1977): “Wet-dog" shake behavior in the rat: A possible quantitative model of central 5-hydroxytryptamine activity. Neuropharmacology 16:663-670

Bischoff C, Tiedtke PI (1992): Competitive and noncompetitive NMDA receptor antagonists in spatial learning tasks. Eur J Pharmacol 213:269-273

Bliss TV, Lomo T (1973): Long-lasting potentiation of synaptic transmission in the dentate area of the anesthetized rabbit following stimulation of the perforant path. J Physiol 232:331-356

Cain DP (1998): Testing the NMDA, long-term potentiation, and cholinergic hypotheses of spatial learning. Neurosci Biobehav Rev 22:181-193

Cain DP, Saucier D, Boon F (1997): Testing hypotheses of spatial learning: The role of NMDA receptors and NMDA-mediated long-term potentiation. Behav Brain Res 84:179-193

Cain DP, Saucier D, Hall J, Hargreaves EL, Boon F (1996): Detailed behavioral analysis of water maze acquisition under APV or CNQX: Contribution of sensorimotor disturbances to drug-induced acquisition deficits. Behav Neurosci 110:86-102

Cain DP, Saucier D, Hargreaves EL, Wilson E, DeSouza, J (1993): Polypropylene pellets as an inexpensive reusable substitute for milk powder in the Morris water maze. J Neurosci Meth 49:193-197

Coan EJ, Saywood W, Collingridge GL (1987): MK-801 blocks NMDA receptor-mediated synaptic transmission and long-term potentiation in rat hippocampal slices. Neurosci Lett 80:111-114

Collingridge GL, Herron CE, Lester RA (1988): Frequencydependent N-methyl-D-aspartate receptor-mediated syn- 
aptic transmission in rat hippocampus. J Physiol 399:301-312

Eichenbaum H, Stewart C, Morris RG (1990): Hippocampal representation in place learning. J Neurosci 10:35313542

Filliat P, Blanchet G (1995): Effects of TCP on spatial memory: Comparison with MK-801. Pharmacol Biochem Behav 51:429-434

Ford LM, Norman AB, Sanberg PR (1989): The topography of MK-801-induced locomotor patterns in rats. Physiol Behav 46:755-758

Goodwin P, Starr BS, Starr MS (1992): Motor responses to dopamine $D_{1}$ and $D_{2}$ agonists in the reserpine-treated mouse are affected differentially by the NMDA receptor antagonist MK 801. J Neural Transm 4:15-26

Grillner S, Georgopoulos AP, Jordan LM (1997): Selection and initiation of motor behavior. In Stein SG, Grillner S, Selverston AI, Stuart DG (eds), Neurons, Networks, and Motor Behavior. Cambridge, MA, MIT Press, pp 3-19

Harris EW, Ganong AH, Cotman CW (1984): Long-term potentiation in the hippocampus involves activation of N-methyl-D-aspartate receptors. Brain Res 323:132-137

Heale V, Harley C (1990): MK-801 and AP5 impair acquisition, but not retention, of the Morris milk maze. Pharmacol Biochem Behav 36:145-149

Hiramatsu M, Cho AK, Nabeshima T (1989): Comparison of the behavioral and biochemical effects of the NMDA receptor antagonists, MK-801 and phencyclidine. Eur J Pharmacol 166:359-366

Kant GJ, Wright WL, Robinson TN, D'Angelo CP (1991): Effects of MK-801 on learning and memory as assessed using a novel water maze. Pharmacol Biochem Behav 39:479-485

Kirk RE (1968): Experimental Design: Procedures for the Behavioral Sciences. Pacific Grove, CA, Brooks/Cole

Koek W, Woods JH, Winger GD (1988): MK-801, a proposed noncompetitive antagonist of excitatory amino acid neurotransmission, produces phencyclidine-like behavioral effects in pigeons, rats, and rhesus monkeys. J Pharmacol Exp Ther 245:969-974

Lehmann-Masten VD, Geyer MA (1991): Spatial and temporal patterning distinguishes the locomotor activating effects of dizocilpine and phencyclidine in rats. Neuropharmacology 30:629-636

Loscher W, Honack D (1992): The behavioral effects of MK801 in rats: Involvement of dopaminergic, serotonergic, and noradrenergic systems. Eur J Pharmacol 215:199208

Mathe JM, Nomikos GG, Hildebrand BE, Hertel P, Svensson TH (1996): Prazosin inhibits MK-801-induced hyperlocomotion and dopamine release in the nucleus accumbens. Eur J Pharmacol 309:1-11

McDonald RJ, White NM (1994): Parallel information processing in the water maze: Evidence for independent memory systems involving dorsal striatum and hippocampus. Behav Neural Biol 61:260-270

McEntee WJ, Crook TH (1993): Review: Glutamate: Its role in learning, memory, and the aging brain. Psychopharmacology 111:391-401

McLamb RL, Williams LR, Nanry KP, Wilson WA, Tilson
HA (1990): MK-801 impedes the acquisition of a spatial memory task in rats. Pharmacol Biochem Behav 37:41-45

Molloy AG, Waddington JL (1984): Dopaminergic behavior stereospecific promoted by the D1 agonist R-SK \& F 38393 and selectively blocked by the D1 antagonist SCH 23390. Psychopharmacology 82:409-410

Morelli M, DiChiara G (1990): MK-801 potentiates dopaminergic $D_{1}$ but reduces $D_{2}$ responses in the 6-hydroxydopamine model of Parkinson's disease. Eur J Pharmacol 182:611-612

Morris RGM (1981): Spatial localization does not require the presence of local cues. Learn Motiv 12:239-260

Morris RGM, Anderson E, Lynch GS, Baudry M (1986): Selective impairment of learning and blockade of longterm potentiation by an N-methyl-D-aspartate receptor antagonist, AP5. Nature 319:774-776

Morris RGM, Garrud P, Rawlins JN, O'Keefe J (1982): Place navigation impaired in rats with hippocampal lesions. Nature 297:681-683

Murata S, Kawasaki K (1993): Common and uncommon behavioral effects of antagonists for different modulatory sites in the NMDA receptor/channel complex. Eur J Pharmacol 239:9-15

Ögren SO, Goldstein M (1994): Phencyclidine- and dizocilpine-induced hyperlocomotion are differentially mediated. Neuropsychopharmacology 11:167-177

Ögren SO, Kehr J, Schött PA (1996): Effects of ventral hippocampal galanin on spatial learning and on in vivo acetylcholine release in the rat. Neuroscience 75:11271140

Ohno M, Watanabe S (1996): Interactive processing between glutamatergic and cholinergic systems involved in inhibitory avoidance learning of rats. Eur J Pharmacol 312:145-147

Pitkanen M, Sirvio J, MacDonald E, Niemi S, Ekonsalo T, Riekkinen P, Sr (1995): The effects of D-cycloserine and MK-801 on the performance of rats in two spatial learning and memory tasks. Eur Neuropsychopharmacol 5:457-463

Rison RA, Stanton PK (1995): Long-term potentiation and N-methyl-D-aspartate receptors: Foundation of memory and neurologic disease? Neurosci Behav Rev 19:533-552

Robinson GS, Crooks GB, Shinkman PG, Gallagher M (1989): Behavioral effects of MK-801 mimic deficits associated with hippocampal damage. Psychobiology 17:156-164

Sandi C, Loscertales M, Guaza C (1997): Experience-dependent facilitating effect of corticosterone on spatial memory formation in the water maze. Eur J Neurosci 9:637-642

Saucier D, Hargreaves EL, Boon F, Vanderwolf CH, Cain DP (1996): Detailed behavioral analysis of water maze acquisition under systemic NMDA or muscarinic antagonism: Nonspatial pretraining eliminates spatial learning deficits. Behav Neurosci 110:103-116

Schött PA, Bjelke B, Ögren SO (1998): Distribution and kinetics of galanin infused into the ventral hippocampus of the rat: Relationship to spatial learning. Neuroscience 83:123-136

Sillito A, Murphy P, Salt T, Moody C (1990): The dependence of retinogeniculate transmission in the cat on NMDA receptors. J Neurophysiol 63:347-355 
Snell LD, Yi SJ, Johnson KM (1988): Comparison of the effects of MK-801 and phencyclidine on catecholamine uptake and NMDA-induced norepinephrine release. Eur J Pharmacol 145:223-226

Tang AH, Ho PM (1988): Both competitive and noncompetitive antagonists of N-methyl-D-aspartic acid disrupt brightness discrimination in rats. Eur J Pharmacol 151:143-146

Wedzony K, Golembiowska K, Zazula M (1994): Differential effects of CGP 37849 and MK-801, competitive and noncompetitive NMDA antagonists, with respect to the modulation of sensorimotor gating and dopamine outflow in the prefrontal cortex of rats. Naunyn-Schmiedebergs Arch Pharmacol 350:555-562

Whishaw IQ, Auer RN (1989): Immediate and long-lasting effects of MK-801 on motor activity, spatial navigation in a swimming pool and EEG in the rat. Psychopharmacology 98:500-507

Whishaw IQ, Cassel JC, Jarrad LE (1995): Rats with fimbriafornix lesions display a place response in a swimming pool: A dissociation between getting there and knowing where. J Neurosci 15:5779-5788

Whishaw IQ, Jarrad LE (1996): Evidence for extrahippocampal involvement in place learning and hippocampal involvement in path integration. Hippocampus 6:513-524

Whishaw IQ, Tomie JA (1997): Perseveration on place reversals in spatial swimming pool tasks: Further evidence for place learning in hippocampal rats. Hippocampus 7:361-370

Wong EH, Nielsen M (1989): The N-methyl-D-aspartate receptor channel complex and the sigma site have different target sizes. Eur J Pharmacol 172:493-496

Wozniak DF, Olney JW, Kettinger LD, Price M, Miller JP (1990): Behavioral effects of MK-801 in the rat. Psychopharmacology 101:47-56

Ylinen A, Pitkanen M, Sirvio J, Hartikainen T, Sivenius J, Koivisto E, Riekkinen PJ, Sr (1995): The effects of NMDA receptor antagonists at anticonvulsive doses on the performance of rats in the water maze task. Eur J Pharmacol 274:159-165 